This item was submitted to Loughborough's Research Repository by the author.

Items in Figshare are protected by copyright, with all rights reserved, unless otherwise indicated.

\title{
The role of private equity when portfolio firms go public: Evidence from ChiNext board
}

PLEASE CITE THE PUBLISHED VERSION

https://doi.org/10.1080/1540496X.2018.1536607

\section{PUBLISHER}

(c) Taylor \& Francis

\section{VERSION}

AM (Accepted Manuscript)

\section{PUBLISHER STATEMENT}

This is an Accepted Manuscript of an article published by Taylor \& Francis in Emerging Markets Finance and Trade on 20 November 2018, available online: http://www.tandfonline.com/10.1080/1540496X.2018.1536607.

\section{LICENCE}

CC BY-NC-ND 4.0

\section{REPOSITORY RECORD}

Li, Yao, Mike Wright, Louise Scholes, and Ziwei Zhang. 2018. "The Role of Private Equity When Portfolio Firms Go Public: Evidence from Chinext Board”. Loughborough University. https://hdl.handle.net/2134/35614. 
The Role of Private Equity when Portfolio Firms go Public:

\section{Evidence from ChiNext board}

Yao Li

(Shanghai University of Finance and Economics, China

Email: liyao@mail.shufe.edu.cn )

Mike Wright

(Imperial College of London, UK

Email: mike.wright@imperial.ac.uk )

Louise Scholes

(Loughborough University, UK

Email: L.Scholes@lboro.ac.uk )

Ziwei Zhang

(Shanghai University of International Business and Economics, China

Email: frank8002@126.com) 
The Role of Private Equity when Portfolio Firms Go Public: Evidence from

\title{
ChiNext Board
}

\begin{abstract}
We probe into the question of why entrepreneurial firms choose to obtain private equity finance (PE) shortly before going public on the ChiNext Board (the Chinese alternative stock market for smaller firms, part of the Shenzhen Stock Exchange, SZSE). Using unique hand-collected data we find that, compared with non-PE-backed firms, firms with PE equity stakes introduced shortly before the IPO did not reduce IPO underpricing or decrease the offering cost. However PE investors increased the probability of approval when the firms applied to the China Securities Regulatory Commission (CSRC) for listing. We suggest the stock issuance rules for the ChiNext should be reformed to lower entrepreneurial firms' financing cost and to encourage PE firms to undertake more value-adding activities.
\end{abstract}

\section{Keywords}

Private Equity, ChiNext, IPO Underpricing, Reputation 


\section{Introduction}

The Chinese capital market is developing and has been able to do so largely without Western-style legal and financial systems (Cumming et al., 2014). One interesting and unexplored aspect of this development is the role that private equity firms play. Private equity firms, as investors in entrepreneurial firms, are generally regarded as holding their investments for several years before seeking an exit, often by a stock market listing. Studies from developed capital markets show that the average holding period by private equity firms before IPO range from 5 to 13 years (Landstrom, 2007; Nahata, 2008; Kaplan and Strömberg, 2009; Blenman and Reddy, 2014). The Chinese growth enterprise market, called the ChiNext Board (ChiNext) in the Shenzhen Stock Exchange, was set up on October 30, 2009 with the ambition of becoming the Chinese version of the NASDAQ or AIM and had the largest value of listings in the world between 2009 and $2012^{\circledR}$. Research on Chinese publicly listed companies on the Shanghai and Shenzhen stock exchanges shows that share transfers from the state to private entities leads to changes in governance that result in significant improvements in company performance (Berkman et al., 2014). These private entities could include private equity firms but they are not identified as such in the sample. Our data from the ChiNext shows that more than $57 \%$ of the listed firms accepted PE investment less than two years before IPO. (2) This raises two intriguing questions: (1) why do these entrepreneurial Chinese firms accept PE capital shortly before listing on a stock exchange? and (2) what is the role of PE in these firms?

The literature provides three perspectives to answer the above questions. The first is whether and how the PE firm can add value to the investee company by improving efficiency or introducing new growth strategies (Fried and Hisrich, 1998; Cyr et al., 2000; Wang et al., 2003; Davila and Foster, 2005; Hsu,2006; Hellmann and Puri, 2000). The second is that the PE firm can play a "certification" role which reduces underpricing, that is, reduce the difference between the offer price and the closing day price of the shares after listing (Megginson and Weiss,1991; Barry et al., 1990; Bruton, et al., 2010). The third is the grandstanding hypothesis which suggests that younger, less experienced, PE firms may take 
their portfolio companies to the market earlier than they should do in order to signal their own ability and thus raise more funds subsequently (Gompers,1996; Lin and Smith, 1998; Lee and Wahal, 2004).

To these arguments we add a fourth. The emerging capital market in China provides an ideal institutional environment to examine the relationship between PE connections and firms' access to the IPO market. While these connections are not measured in this article it is nevertheless important to understand what they are and how they will impact certification and grandstanding. The IPO process in the Chinese capital market is strictly regulated by the Chinese government. In particular, in the early stages of the Chinese IPO market, whether a firm can enter the IPO market was directly allocated by Chinese central and local government. Along with market-oriented reform in the Chinese capital market, such direct governmental intervention has been greatly reduced since 2004, but Chinese companies still must submit an IPO application to the China Securities Regulatory Commission (CSRC), which is also an authority of the Chinese government. Firms cannot issue new shares in the capital market until that application has been approved. Given that the IPO screening process is essential for pre-IPO firms and direct governmental intervention has been reduced, firms' unique connections become important as they allow for more effective communication with the regulators and for firms to be better able to meet their regulatory requirements. These connections are referred to as political connections in several studies (Berkman et al., 2010; Chen et al., 2011. Claessens et al., 2008; Liu et al. 2014; Bao et al.2016) and acts in conjunction with certification and grandstanding.

The CSRC regulates new entrants to the stock market via its Stock Issuance Examination and Verification Committee (SIEVC), which consists of auditors, lawyers, government officials, fund managers and scholars. The membership list of the SIEVC is public $^{(3)}$. The ability of the committee to judge the quality of a business is questionable as most members of the committee do not have industrial experience, and in addition, they may be susceptible to favoritism. As a result, PE investment may act as a mechanism to facilitate acceptance by the committee. This is a 'certification' effect relating to the regulators not just to the 'market' as in the traditional certification literature. We argue that the underlying reason for the popularity of $\mathrm{PE}$ investment (PE as quick flippers) is the higher approval rating 
for listing on the ChiNext for firms with PE. The approval system potentially lures PE firms into using undesirable tactics. Thus PE firms may give up their core ethos of adding value to investee firms in favor of pushing the enterprises to IPO as early as possible using their GUANXI resources. In China, the institutional background has determined the relationship (GUANXI) resources crucial to business success (Luo, 2000; Yeung and Tung, 1996). The PE investment needs more GUANXI resources besides the capital to operate in China. Previous literature found that PE endeavored to establish GUANXI with the investee firm's founder (the founder himself, his/her family, colleagues or classmates) diligently in order to better monitor the enterprise (Bruton and Ahlstrom, 2003).

Existing literature does not provide a comprehensive explanation for the effects of PE investment in China (Wright, 2007; Zhang and Liao, 2011; Chen et al., 2011; Wu et. al., 2012; Guo and Jiang, 2013; Jiang et al., 2014). Our paper contributes by highlighting different roles of PE investors in IPOs in China and by identifying policy implications. Our evidence questions the effectiveness of the ChiNext in fulfilling its original intention of stimulating enterprise growth and also to catalyze industry transformation in China by encouraging the formation of a PE industry. Our findings imply that there is a need to change the way enterprises are assessed for ChiNext listings.

The remainder of the paper proceeds as follows. Section 2 reviews the literature and presents the hypotheses. Section 3 describes the data and methods we used in the empirical work. Section 4 provides the empirical results. Section 5 discusses our findings and concludes.

\section{Background, literature and hypothesis}

\subsection{Background: the Approval System in Chinese IPOs and the Popularity of PE-Funded Listings}

The China Securities Regulatory Commission (CSRC) regulates new entrants to the stock market via its SIEVC. Only "excellent" firms are permitted to be listed on the public market.

The government's strict control causes the supply of firms on the IPO market to be insufficient. A firm's successful going public means tremendous benefits, such as a premium 
valuation, the convenience of refinancing, the opening up of more business opportunities, raising the profile of management, and showcasing a political achievement for local government. As a consequence of these benefits, companies may be willing to endure the high cost involved in IPO underpricing and equity dilution. That is, what the firms need most is someone to help them to get listing approval.

PE may act as a mechanism to facilitate acceptance for listing. Some literature documents that IPO applications of politically connected firms are more likely to be approved by regulators in China, which means that political connections facilitate firms' access to the IPO market (Fan et al., 2007; Liu et al., 2014; Bao et al., 2016 ) ${ }^{\circledR}$. Political connections in entrepreneurial firms help them to overcome market and institutional barriers and to obtain favourable treatment from the government under the weak institutional environment that exists in China (Li, et al., 2008; Wu, Wu and Rui, 2010; Chen, 2013). Following the same logic, we argue that the underlying reason for the popularity of PE investment is the higher probability of approval for listing on the ChiNext. Meanwhile the success of the IPO will also have a positive effect on the reputation of the PE firm, enhancing their ability to attract subsequent funds. Under the Chinese institutional environment, entrepreneurial firms tend to establish and maintain a close relationship with the government through the PE shareholder in order to mitigate possible ideological discrimination and get better access to external financial resources.

\subsection{Approval Probability: Rent-seeking and PE Firms' GUANXI}

The approval regulation for the issuance of securities by CSRC is essentially a government control system. Stigler (1971) argues that government control creates rents. As a result of competition between interest groups, government regulation will be biased and give preference to well organized interest groups. McChesney (1987) argued that officials will abuse their power to intervene in the market, leading to the creation of rent-seeking opportunities for market players. He and Wang (2000), Qi (2003), and Zhu (2009) have studied this topic and find some evidence of "rent seeking" in the Chinese IPO process. Firms seeking to access public funding in China's underdeveloped legal and financial systems rely more heavily on its political network to obtain favorable regulatory conditions, in this case 
approval of listing applications.

For the approval system of the Chinese IPO market, PEs may have a special relationship with the SIEVC. The role of the CSRC encourages financial intermediaries, including PE, to engage in lobbying activities to obtain approval on behalf of enterprises in which they have invested. PE institutions obviously have advantages compared to other applicants when applying to CSRC for approval. As financial professionals, they have industry experience, regional concentration, and relationships with members of SIEVC ${ }^{5}$. They also provide the certification role for the investment, identified elsewhere in different markets around the world. Therefore, the approval rules for issuing securities are more likely to give preference to PE institutions. Hence:

H1a: PE-backed firms have a higher approval probability than non PE-backed firms.

As described above, the nature of the approval system in IPO is a government controlled process. It undermines the original relationship between market players, resulting in alienation of market players. The regulation of IPOs also leads to a shortage of supply. In the Chinese IPO market firms only care about getting approval from the SIEVC, few worry about subscription (demand) insufficiency or even failure on the public offering market as long as they get the approval document from the CSRC. For startups, the most important goal is growth and therefore pleasing the SIEVC in order to obtain a listing, is critical. Younger firms usually have more growth opportunities than their older peers so obtaining approval from the CSRC and then going public to achieve external funding is thus more valuable for them. For PE firms, what is more important is improving their reputation through listing rather than adding value to portfolio enterprises (Bruton and Ahlstrom, 2003). The combination of the enterprise and a PE may therefore be able to influence the SIEVC sufficiently for listing. Since the stock issuance system endows regulators with great powers on resource allocation, PE firms may seek to take advantage of their GUANXI in the IPO application process, and collect a rent-like charge. If this is the case, the different background of PE firms means different lobbying power during the IPO application process. In particular, the active PE firms in the ChiNext market have a good reputation, such as the top PE firms in 
China, state-owned PE firms or foreign PE firms with a track record. That is to say, PE institutions with higher reputation should have a positive influence on all stakeholders including the CSRC which leads to the following hypothesis:

H1b: Reputable PE-backed firms have higher approval probability than non-reputable PE-backed firms.

\subsection{IPO Underpricing: Certification vs. Grandstanding}

Information asymmetry often leads to an expensive financing loss (underpricing) for IPO firms, especially in Chinese stock markets (Ritter and Welch, 2002; Ljungqvist, 2007; Xu and Luo, 2007; Zhu and Qian, 2010; Jiang et al., 2014). Many studies have examined whether PE can reduce information asymmetry, so as to reduce underpricing. Megginson and Weiss (1991) argued that PE backing could play the role of certification in the process of the IPO. They found that PE-backed enterprises have a significantly lower underpricing ratio compared to nonPE-backed enterprises. Barry et al. (1990) argued that PE investors have the ability to screen deals effectively before they invest, delivering a signal to the market that the enterprise is of higher quality, so reducing underpricing. These points were supported by Brav and Gompers (1997) and Wang et al. (2003) but there are also opposite viewpoints. Gompers (1996) proposed the grandstanding hypothesis and argued that young PEs are under more pressure to establish a reputation to attract new funds. Therefore they have a stronger motivation to push immature companies to IPO, which may lead to greater underpricing and poorer post-IPO performance of PE-backed enterprises. Lee and Wahal (2004) support this grandstanding hypothesis.

Reputation is critical for the PEs who want to gain legitimacy in the market (Gompers, 1996). The reputation of PE firms can bring positive effects to their portfolio enterprises, for example, attracting customers, suppliers, and talented managers (Davila et al., 2003). Only mature PEs with good reputations can play a certification role. Young PE firms clearly cannot meet the above requirements, and it is a rational choice for them to push the enterprises in which they invest to IPO as soon as possible in order to establish a reputation. 
A good reputation gives the PE firms more market power. Even if valuations for investees are slightly lower than that of competitors without reputation, their offers are more inclined to be accepted by the entrepreneur (Hsu, 2004). The good reputation also enhances their ability to raise new funds, and to sell their portfolio enterprises to third parties (Gompers, 1996). Resourcefulness of investors, for example past experience in the industry, could also help to reduce underpricing, signaling to the market that less negative information is likely to be divulged after the listing.

There is a paucity of research on PE in China as it is a relatively new phenomenon. Kou et al. (2009), Tan et al.(2009), Zhang and Liao (2011), Chen et al. (2011), and Otchere and Vong (2016) document that the PE certification role has different manifestations in different markets. While PE does a good certification job in the UK and US markets, it does not reduce underpricing in emerging markets such as in mainland China and Hong Kong. However these studies are focused on IPOs on the main board of the Chinese stock market.

The PE market and the ChiNext stock exchange are both very young in China, so most PE investors have very little track record, hence their ability to screen and certify is uncertain. Exiting by IPO could bring significant profits to the PE funds which could be regarded as the best way to establish a reputation. Reputation and resourcefulness of PE firms can however still potentially reduce underpricing thus we put forward the following hypotheses:

H2a: PE-backed enterprises have higher underpricing than non-PE-backed firms.

$H 2 b$ Reputable PE-backed firms have lower underpricing than non-reputable PE-backed firms.

\section{The Sample, Variables and Method of Analysis}

\subsection{The Sample}

PE is defined as having the following characteristics: The PE investment is within a period of two years before the listing. ${ }^{\odot}$ The investee is a non-publicly traded company; The PE capital is privately placed from special institutions or individuals. We categorize the shareholders in the firm's IPO prospectus into enterprise insiders (including founder, management, staff and other affiliated shareholders), PE investors holding shares for up to 
two years before IPO, PE investors holding shares more than two years before IPO (Long PE), and other investors (including angels, strategic investors and other company investors).There are two reasons for us to use a boundary of two years to classify the PE investments. Firstly, under Chinese tax policy entrepreneurial firms' shareholders with more than two years holding period can be entitled to preferential tax treatment ${ }^{\odot}$. Secondly, following interviews with practitioners (including PE managers, entrepreneurs, IPO underwriters, etc.), we find that they generally agree that two years is a reasonable boundary for the PE investments.

We examine all IPO applications from September 17, 2009 to November 3, 2012 ${ }^{\circledR}$, a period during which 494 companies submitted applications to the CSRC for listing on ChiNext, including 355 companies successfully listed, 46 companies approved but still in the waiting period until the end of 2012, and 93 companies rejected. According to the "Interim Measures for Initial Public Offerings and Listing on ChiNext" published by CSRC on April 2, 2009 , the enterprises should issue their shares within 6 months after receiving approval from the CSRC. In the following analysis, we omitted the PE investors who have backed the firms for more than 2 years before the firm came to IPO, which are not quick flippers. We analyze Pre-IPO PE-backed firms and non-PE backed firms. Overall the sample involves 357 enterprises, including 254 companies successfully listed, 32 companies approved but still in the waiting period until the end of 2012, and 71 companies rejected. The statistical description of the sample is shown in Table 1.

From each prospectus of the 357 firms we hand-collected data on the characteristics of the PE investment: holding share ratio, holding time, whether PE acts as a manager or director of the company, the patent owning, etc. Other data such as financial performance, market transaction, underwriter information of the firms come from the $\operatorname{CSMAR}^{\oplus}$ and WIND databases. ${ }^{10}$ We collected the IPO application data including prospectuses from the WIND database.

Since there is no authorized database for PE investors in China, existing literature often uses indirect data. For example, the CSMAR database collects "top ten shareholders", and uses key words such as "investment", "venture capital ", "private capital", "venture", "limited partnership" and so on to screen the shareholders' names. If the screening result is YES, the shareholder is regarded as a PE firm and the enterprise as a PE-holding one. We find this 
method is biased when we recheck it by hand-collected data. ${ }^{11}$ To sum up, we identify a shareholder as a PE investor if the biography of shareholder in the prospectus states that the institution is "mainly engaged in VC/PE" and "does not have any relationship with founders, actual controller or chief managers of the IPO applicant".

Data is collected for firms for year 0 (year of IPO), year -1 (1 year before IPO), year -2 (2 years before IPO) and year -3 (3 years before IPO). For example, ROA-1 in the Tables means the ROA one year before IPO.

\subsection{The Variables}

\section{$\underline{\text { Dependent Variables }}$}

The first dependent variable Approval (models 1-2) used to test H1a, H1b, is defined as a binary variable, which is 1 if the sample company was approved by the SIEVC, and 0 otherwise.

The second dependent variable IPO Underpricing (model 3), used to test $\mathrm{H} 2 \mathrm{a}, \mathrm{H} 2 \mathrm{~b}$, is defined as:

$$
\text { Underpricing }=\frac{\text { Close price of first trading day }- \text { Offering price }}{\text { Offering price }}
$$

\section{$\underline{\text { Independent Variables }}$}

$P E$ is the key explanatory variable and is coded 1 if the firm is backed by a PE investor, 0 otherwise. PE institutions are divided into two categories: those with reputation (ReputablePE=1), otherwise ReputablePE=0. If a PE firm is among the 'Annual Ranking of Top 10 private equity firms or Top 20 venture capital firms in mainland China' in any one of the previous two years before the investee's IPO, it is defined as with reputation, otherwise, it has no reputation. The PE and VC rankings are disclosed by Zero2IPO group which is the leading data provider in the Chinese PE/VC industry. ${ }^{12}$ According to the China Ministry of Finance and the State-owned Assets Supervision and Administration Commission (SASAC, 2009), if a sponsor shareholder of a listed company is state-owned, the state shareholder must transfer $10 \%$ of its holding equity to the National Social Security Fund (NSSF)before IPO. The IPO prospectus discloses the nature of all shareholders. State shareholders are labeled as "SS". PE shareholders are classified as SS or not according to whether the PE is state-owned. 
So any PE investor is thus either state-owned PE $($ StatePE $=1)$ or not $($ StatePE $=0)$.Among those non-state-owned PE some are foreign-owned PE (ForeignPE=1), some are not (ForeignPE $=0$ ). PE reputation is therefore a combination of ReputablePE, StatePE, and ForegnPE.

\section{Control Variables}

In model 1-2 there are three kinds of control variables: The first aims at controlling for risky factors: the firms' age when IPO (Age), the total assets one year before IPO (Size-1), the profit margin (ROA-1), the asset-liability ratio (BS-1), the reputation of underwriter (Underwriter), the operation risk factors disclosed in the prospectus (Risk-1). ${ }^{13}$ The second aims at controlling for future development potentiality: the R\&D investment/operating income (Research-1), and the number of patented copyright and non-patented technology (Patent-1). And the third aims at controlling for the sentiment of the secondary market, which was regarded as a metronome for IPO frequency. In addition, we impose other control variables such as industry dummy (Industry) and annual dummy (Year). The industry dummy is based on the WIND database industry classification.

In model 3, we use two types of control variables in line with the literature. The first type represent information asymmetry (Deng and Zhou, 2016a,b), that is, idiosyncratic risk of firms including the total assets one year before IPO (Size_1), the firm's history (Age), total return on assets (ROA-1), underwriter reputation (Underwriter), IPO P/E ratio (P/E), the firm's capital structure(Leverage_1), the firms growth rate (Growth_1), the issuing volume (IssueSize). The second type represents investors' emotional factors such as the online lottery rate (Lottery) ${ }^{14}$, and total market trading volume on the first trading day (Volume).

\subsection{The Method of Analysis}

\section{Approval Probability and PE}

We first test hypothesis H1a with the following probit model with the firms who have applied for listing in the ChiNext:

Approval $=\beta_{0}+\beta_{1} P E+\beta_{2} \log ($ Age $)+\beta_{3} \log \left(\right.$ Size $\left._{-} 1\right)+\beta_{4} R O A_{-} 1+\beta_{5} B S S_{-} 1$ 


$$
+\beta_{6} \text { Underwriter }+\beta_{7} \log (\text { Risk })+\beta_{8} \log (\text { Patent })+\beta_{9} \log (\text { Index })
$$

To test hypothesis H1b we classify reputation in three ways such as ReputablePE, StatePE (state-owned PE) or ForeignPE (foreign-owned PE). These labels describe the backgrounds of the PE institutions and are used as proxy variables for the relationship/GUANXI that they have. The probit model is as follows:

$$
\begin{aligned}
\text { Approval }= & \beta_{0}+\beta_{1} \text { ReputablePE }+\beta_{2} \text { StatePE }+\beta_{3} \text { ForeignPE } \\
& +\beta_{4} \log (\text { Age })+\beta_{5} \log (\text { Size } 1)+\beta_{6} \text { ROA } 1+\beta_{7} B S_{-} 1 \\
& +\beta_{8} \text { Underwriter }+\beta_{9} \log (\text { Risk })+\beta_{10} \log (\text { Patent })+\beta_{11} \log (\text { Index })
\end{aligned}
$$

\section{IPO Underpricing and PE}

To test hypothesis $\mathrm{H} 2 \mathrm{a}$ and $\mathrm{H} 2 \mathrm{~b}$ we build a multivariate regression model with the whole sample of listed firms.

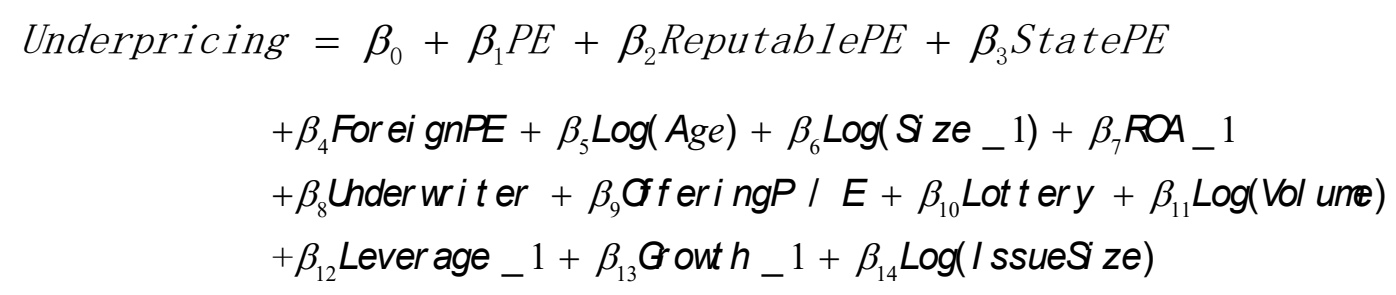

\section{Results}

\subsection{Descriptive statistics}

Summary data on PE investors in the ChiNext listed companies is shown in Table 1. In our full sample, $38.38 \%$ of the firms have PE investors before listing. For the subsample of being approved by CSRC, more than $40.94 \%$ of the firms accepted PE. While for the subsample of firms rejected by CSRC, $21.13 \%$ had PE. In addition, we find that there are on average 2.12 PEs per IPO firm.

\section{Table 1. The PE investors in firms applying for ChiNext board listing}

The sample includes the IPO applications of pre-IPO PE-backed firms (PE holding time is less than two years before IPO) and non-PE backed firms from September 17, 2009 to November 3, 2012. The characteristics of the PE investment as holding share ratio, holding time, whether PE acts as a manager or director of the company, the patent owning are hand-collected. If a PE firm is among the 'Annual Ranking 
of Top 10 private equity firms or Top 20 venture capital firms in mainland China' disclosed by Zero2IPO group in any one of the previous two years before the investee's IPO, it is defined as reputable PE. If a PE shareholder is labeled as "SS" (State shareholders) in IPO prospectus then the PE is state-owned. Those non-SS PE with foreign LP or GP are foreign-background PE.

\begin{tabular}{lcccc}
\hline & $\begin{array}{c}\text { Approved } \\
\text { and Listed }\end{array}$ & $\begin{array}{c}\text { Approved } \\
\text { but }\end{array}$ & Rejected & All \\
& & waiting & & \\
\hline Number of firms & 254 & 32 & 71 & 357 \\
Number of firms backed by PE & 104 & 18 & 15 & 137 \\
Proportion of PE backed firms & $40.94 \%$ & $56.25 \%$ & $21.13 \%$ & $38.38 \%$ \\
Number of PE investors & 209 & 38 & 43 & 290 \\
Average number of PE in each firm & 2.01 & 2.11 & 2.87 & 2.12 \\
\hline Average holding share ratio of PE & $11.52 \%$ & $17.90 \%$ & $18.00 \%$ & $13.07 \%$ \\
\hline Average holding time of PE(year) & 0.68 & 0.49 & 0.57 & 0.64 \\
\hline Average PE investors serve as CEO & $6.73 \%$ & $6.42 \%$ & $6.67 \%$ & $6.68 \%$ \\
\hline Average PE investors serve as a & $65.21 \%$ & $73.33 \%$ & $63.33 \%$ & $66.07 \%$ \\
director or supervisor & & & & \\
\hline Proportion of reputable PE & $54.81 \%$ & $22.22 \%$ & $26.67 \%$ & $47.45 \%$ \\
\hline Proportion of state-owned PE & $18.27 \%$ & $16.67 \%$ & $6.67 \%$ & $16.79 \%$ \\
\hline Proportion of foreign background PE & $9.62 \%$ & $11.11 \%$ & $20 \%$ & $10.95 \%$ \\
\hline
\end{tabular}

For the characteristics of PE investors' shareholding, the average holding ratio of PE is $13.07 \%$. The average holding time of PE is 0.64 years. $6.68 \%$ of $\mathrm{PE}$ investors serve as CEO in the firms. And $66.07 \%$ of PE investors serve as a director or supervisor in the investee firms. As for the background of the PE, $47.45 \%$ have a reputation, $16.79 \%$ are state-owned, $10.95 \%$ are of foreign background.

Table 2 presents the characteristics of all firms before IPO. Compared with non PE-backed firms, the PE backed firms have younger ages, smaller total assets, more patents, larger boards and management, higher average management compensation in means, although not statistically different. And besides that, PE backed firms are more likely to change CFO within two years before IPO, also not statistically different. These findings mean 
that there are some differences between PE backed firms and the others, and there would be distinctive reasons for enterprises to accept PE investors.

\section{Table2. Characteristics of ChiNext firms before IPO $(n=357)$}

The sample includes the IPO applications of pre-IPO PE-backed firms(PE holding time is less than two years before IPO) and non-PE backed firms from September 17, 2009 to November 3, 2012. The general and governance characteristics are from IPO prospectuses which are downloaded from the WIND database.

\begin{tabular}{|c|c|c|c|c|}
\hline & PE-backed & $\begin{array}{c}\text { Non } \\
\text { PE-backed }\end{array}$ & All & $\begin{array}{c}\text { T-valu } \\
\mathrm{e}\end{array}$ \\
\hline \multicolumn{5}{|l|}{ Panel A. General characteristics } \\
\hline Age(years) & 10.82 & 11.51 & 11.25 & -0.771 \\
\hline total assets (in RMB10 thousand) & 50677.17 & 59813.56 & 56307.44 & -0.515 \\
\hline total return on assets $(\%)$ & 18.52 & 17.85 & 18.11 & 0.994 \\
\hline total return on earnings $(\%)$ & 30.14 & 29.74 & 29.89 & 0.718 \\
\hline asset-liability ratio (\%) & 39.47 & 39.53 & 39.51 & -0.225 \\
\hline risk disclosed & 13.11 & 12.87 & 12.96 & 0.762 \\
\hline the number of patents owned & 36.72 & 28.13 & 31.43 & 0.381 \\
\hline \multicolumn{5}{|l|}{ Panel B. Governance Features } \\
\hline shareholding ratio of largest shareholder $(\%)$ & 59.15 & 58.46 & 58.72 & 0.220 \\
\hline management members & 18.13 & 17.04 & 17.46 & 0.383 \\
\hline number of board directors & 12.09 & 11.02 & 11.43 & 0.673 \\
\hline number of senior experts & 5.87 & 5.54 & 5.67 & 1.200 \\
\hline number of senior financial experts & 1.81 & 1.68 & 1.73 & 1.142 \\
\hline average age of management & 43.21 & 43.96 & 43.67 & -0.981 \\
\hline average managers compensation (RMB10 & 14.07 & 13.92 & 13.98 & 0.326 \\
\hline thousand) & & & & \\
\hline whether CFO changed within two years & 0.39 & 0.25 & 0.30 & 0.769 \\
\hline before IPO & & & & \\
\hline
\end{tabular}

Table 3 describes the IPO features of PE-backed firms. We find that compared with non 
PE-backed firms, PE backed firms have a more real gross proceeds, higher offering fees, more reputable underwriters with statically significance. PE backed firms also have lower lottery ratio in offline while higher lottery rate in online markets, higher underpricing of the first trading day, and higher one year buy and hold abnormal return in means, although not statistically different. These differences show that PE investors took some distinctive influence to their portfolio firms in the IPO process.

\section{Table 3. Characteristics of IPOs of ChiNext firms}

The sample includes the listed firms who are pre-IPO PE-backed firms (PE holding time is less than two years before IPO) and non-PE backed firms from September 17, 2009 to November 3, 2012. The financial performance, market transaction, underwriter information of the firms is collected from the CSMAR and WIND database.

\begin{tabular}{|c|c|c|c|c|}
\hline & PE-backed & $\begin{array}{c}\text { Non } \\
\text { PE-backed }\end{array}$ & All & T-value \\
\hline $\begin{array}{l}\text { Average number of offering } \\
\text { shares }(10,000)\end{array}$ & 2250.56 & 2284.89 & 2270.83 & -0.926 \\
\hline IPO $\mathrm{P} / \mathrm{E}$ ratio & 54.72 & 55.10 & 54.94 & -0.271 \\
\hline Real gross proceeds (RMB/100 million) & 2.75 & 2.29 & 2.48 & $2.263^{* *}$ \\
\hline Offering fee (RMB/100 million) & 0.47 & 0.44 & 0.45 & $1.933^{*}$ \\
\hline Underwriters reputation & 0.65 & 0.54 & 0.59 & $2.302^{* *}$ \\
\hline Lottery ratio for offline IPO shares (\%) & 6.78 & 6.98 & 6.90 & -0.775 \\
\hline Lottery ratio for online IPO shares (\%) & 1.77 & 1.36 & 1.53 & 1.351 \\
\hline Underpricing rate( $\%)$ & 33.53 & 30.74 & 31.88 & 0.706 \\
\hline $\begin{array}{l}\text { Market adjusted first day underpricing } \\
\text { rate }(\%)\end{array}$ & 33.47 & 30.91 & 31.96 & 0.636 \\
\hline $\begin{array}{l}120 \text { days buy and hold abnormal return } \\
(\%)\end{array}$ & 33.55 & 33.23 & 33.36 & 0.175 \\
\hline $\begin{array}{l}250 \text { days buy and hold abnormal return } \\
(\%)\end{array}$ & 36.94 & 34.17 & 35.30 & 0.032 \\
\hline
\end{tabular}

We also find that Chinese PE investments show an 'industrial clustering' effect (Lerner et 
al. 2004) and a 'geographic concentration' effect where shorter distances are preferred in order to reduce monitoring and transaction costs (Lee and Wahal, 2004; Tian, 2007). It shows that $66.28 \%$ of the enterprises are clustered in four industries: capital goods, software and services, material, and technological hardware and equipment. And $69.72 \%$ of the PE investments are concentrated in the four industries. The statistics also show that $63.18 \%$ of the ChiNext firms concentrate in five provinces or municipalities: Guangdong, Beijing, Zhejiang, Jiangsu and Shanghai, and $67.61 \%$ of the PE backed firms locate there. Also most of the Chinese PE institutions are headquartered in the above five provinces or municipalities.

\subsection{Approval Probability}

The PE-backed firms have a significantly higher possibility to get an approval at the SIEVC of CSRC when applying for listing (Table 4). The coefficient for the effect of PE on the approval probability is 0.461 and is highly significant (Column 4 in Table 4). That is, introducing PE has significantly increased the probability of approval by 0.461 at CSRC. But for the underwriters' reputation, a well-reported phenomenon in the academic literature, the results show no significance. In addition, we find significant variables include total assets (Size-1), the total assets profit margin $(R O A-1)$ and the asset-liability ratio(BS_l). That is, the bigger the total assets, the higher profitability, and the lower debt level of the enterprise, the easier the firm is to get approved. The result is in alignment with other scholars' findings (Megginson and Weiss, 1991; Ljungqvist, 2007; Liu and Xiong, 2005), also is consistent with the CSRC restrictive requirements ${ }^{15}$. But other risky and potentiality indicators show no significant effect. The findings give support to Hypothesis 1a, that PE-backed firms have a significantly higher probability of a stock market listing.

\section{Table 4. Influence of PE on the probability of listing approval (H1a, Model 1)}

Regressions for the influence of PE background on the probability of the listing approval. The dependent variable is the approval dummy ( 1 if listing approved, otherwise 0 ). The explanatory variable is the PE dummy ( 1 if the firm is backed by a PE investor, otherwise 0$)$. The control variables include the logarithm of the firm's age when approval for IPO (LogAge), the logarithm of the firm's total assets one year before approval (LogSize_1), the firm's return on assets one year before approval (ROA_1), the firm's asset-liability ratio one year before approval (BS_1), the dummy variable that equals to one if the underwriter is reputable, zero otherwise (Underwriter), the logarithm of the firm's operational risk factors 
disclosed in the prospectus one year before approval (Logrisk), the logarithm of the number of the firm's patented copyright and non-patented technology (Logpatent), the sentiment of the secondary market to measure the metronome for IPO frequency (Logindex), the industry dummy variables and the censor year dummy variables. The brackets present $\mathrm{z}$ values, and ***,**,* indicate $1 \%, 5 \%$, and $10 \%$ significance level respectively. There are 357 samples, while due to a small lack of independent variables, the available sample size is changing in column(1)-(4).

\begin{tabular}{|c|c|c|c|c|}
\hline \multirow[b]{2}{*}{ Independent variable } & \multicolumn{4}{|c|}{ Approval } \\
\hline & (1) & (2) & (3) & (4) \\
\hline$\overline{P E}$ & $0.602^{* * *}$ & $0.653^{* * *}$ & $0.447^{* *}$ & $0.461^{* *}$ \\
\hline & $(3.28)$ & $(3.21)$ & $(1.99)$ & $(2.01)$ \\
\hline \multicolumn{5}{|l|}{$\underline{\text { Controls }}$} \\
\hline \multirow[t]{2}{*}{ LogAge } & & -0.165 & -0.118 & -0.136 \\
\hline & & $(-0.65)$ & $(-0.40)$ & $(-0.48)$ \\
\hline \multirow[t]{2}{*}{ LogSize_1 } & & $0.605^{* * *}$ & $0.555^{* *}$ & $0.519^{* *}$ \\
\hline & & $(2.76)$ & $(2.26)$ & $(2.10)$ \\
\hline \multirow[t]{2}{*}{$R O A_{-} 1$} & & $1.385^{* * *}$ & $1.320^{* * *}$ & $1.308^{* * *}$ \\
\hline & & $(4.13)$ & $(3.71)$ & $(3.63)$ \\
\hline \multirow[t]{2}{*}{$B S_{-} 1$} & & 1.488 & $1.876^{*}$ & $2.016^{*}$ \\
\hline & & $(1.50)$ & $(1.76)$ & $(1.88)$ \\
\hline \multirow[t]{2}{*}{ Underwriter } & & & 0.258 & 0.281 \\
\hline & & & $(1.29)$ & $(1.38)$ \\
\hline \multirow[t]{2}{*}{ LogRisk } & & & 0.225 & 0.187 \\
\hline & & & $(0.76)$ & $(0.63)$ \\
\hline \multirow[t]{2}{*}{ LogPatent } & & & -0.0321 & -0.0388 \\
\hline & & & $(-0.34)$ & $(-0.42)$ \\
\hline \multirow[t]{2}{*}{ LogIndex } & & & & 1.653 \\
\hline & & & & $(1.38)$ \\
\hline \multirow[t]{2}{*}{ _cons } & $0.592^{* *}$ & $-9.962^{* * *}$ & $-10.09^{* * *}$ & $-22.35^{* *}$ \\
\hline & $(2.33)$ & $(-3.48)$ & $(-3.10)$ & $(-2.36)$ \\
\hline Industry & $\sqrt{ }$ & $\sqrt{ }$ & $\sqrt{ }$ & $\sqrt{ }$ \\
\hline Year & $\sqrt{ }$ & $\sqrt{ }$ & $\sqrt{ }$ & $\sqrt{ }$ \\
\hline chi2 & 22.39 & 42.49 & 40.26 & 39.51 \\
\hline Log likelihood & -156.42 & -139.90 & -109.36 & -108.26 \\
\hline Pseudo R2 & 0.17 & 0.14 & 0.14 & 0.15 \\
\hline$N$ & 345 & 338 & 283 & 281 \\
\hline
\end{tabular}

In the robustness check we use the Heckman model to control for self-selection bias with three instrument variables including the firm's total assets at 3 years before IPO, average industry $\mathrm{P} / \mathrm{B}$ ratio at 3 years before IPO, and a year dummy variable. We choose the instrumental variables as they are significantly correlated with the decision of entrepreneurs to accept a PE investor. The result shows that there is no significant self-selection bias. 
Table 5. Influence of PE reputation on the probability of listing approval (H1b, Model 2)

Regressions for the influence of PE background on the probability of the listing approval. The sample is $137 \mathrm{PE}$ backed firms from 2009 to 2012.The dependent variable is the approval dummy ( 1 if listing approval, otherwise 0 ). Independent variables include the three kinds PE background dummy variables: ReputablePE equals to one if the PE is reputable, zero otherwise. StatePE equals to one if the PE is SS labeled in prospectus, zero otherwise. Foreign PE equals to one if a non-SS labeled PE whose partner has foreign-background, zero otherwise. The control variables include the logarithm of the firm's age when approval for IPO (LogAge), the logarithm of the firm's total assets one year before approval (LogSize_1), the firm's return on assets one year before approval (ROA_1), the firm's asset-liability ratio one year before approval (BS_1), the dummy variable that equals to one if the underwriter is reputable, zero otherwise (Underwriter), the logarithm of the firm's operational risk factors disclosed in the prospectus one year before approval (Logrisk), the logarithm of the number of the firm's patented copyright and non-patented technology (Logpatent), the sentiment of the secondary market to measure the metronome for IPO frequency (Logindex), the industry dummy variables and the censor year dummy variables. The brackets present $\mathrm{z}$ values, and $* * *, * *, *$ indicate $1 \%, 5 \%$, and $10 \%$ significance level respectively. There are 104 samples, while due to a small lack of independent variables.

\begin{tabular}{cccc}
\hline \hline & & & \\
Independent variable & $(5)$ & $(6)$ & $(7)$ \\
\hline ReputablePE & 0.533 & & \\
StatePE & $(1.41)$ & $1.175^{* *}$ & \\
& & $(2.17)$ & -0.248 \\
Controls & & & $(-0.35)$ \\
ForeignPE & & & 0.777 \\
& & & $(1.02)$ \\
LogAge & 0.738 & 0.815 & $1.136^{* *}$ \\
& $(1.06)$ & $(0.99)$ & $(2.01)$ \\
LogSize_1 & $1.272^{* *}$ & $1.024^{* *}$ & $1.711^{* * *}$ \\
& $(2.42)$ & $(1.94)$ & $(2.64)$ \\
ROA_1 & $1.745^{* * *}$ & $1.931^{* * *}$ & -2.487 \\
& $(2.65)$ & $(2.90)$ & $(-0.75)$ \\
BS_1 & -2.518 & -1.471 & $1.400^{* *}$ \\
& $(-0.81)$ & $(-0.48)$ & $(2.46)$ \\
Underwriter & $1.395^{* *}$ & $1.477^{* * *}$ & 0.761 \\
& $(2.22)$ & $(2.68)$ & $(1.29)$ \\
LogRisk & 0.780 & 0.702 & $-0.550^{* *}$ \\
& $(1.43)$ & $(1.23)$ & $(-2.24)$ \\
LogPatent & $-0.561^{* *}$ & $-0.596^{* *}$ & -1.356 \\
& $(-2.32)$ & $(-2.53)$ &
\end{tabular}




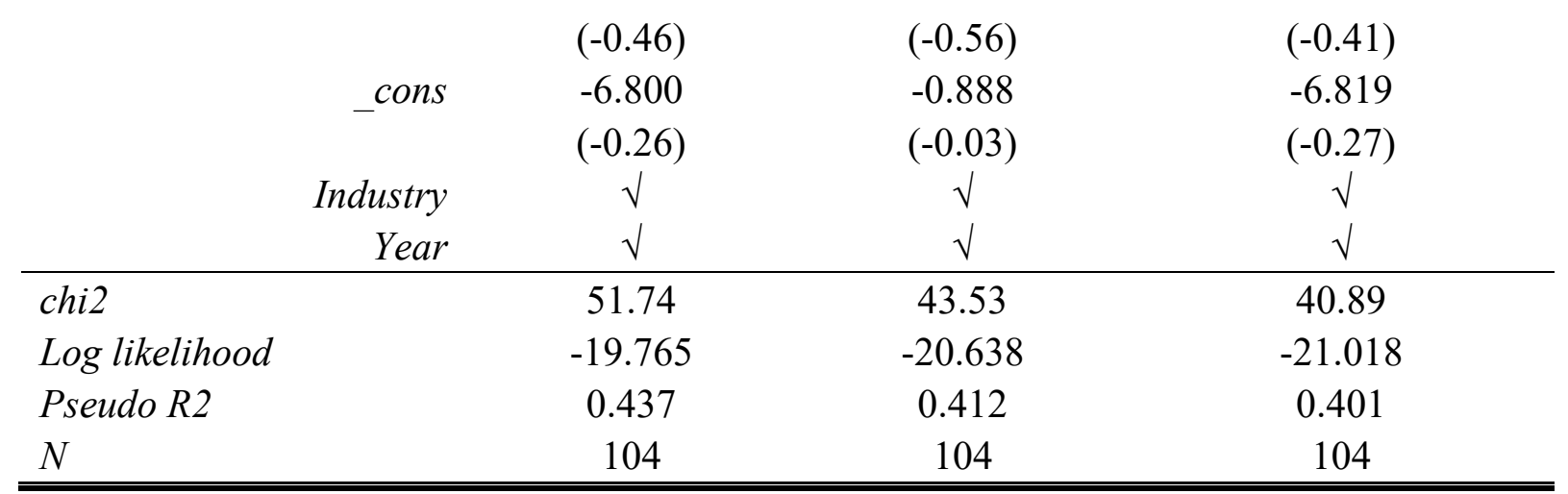

Compared to the samples with no reputation, PE with reputation (ReputablePE) can not increase or decrease the approval probability. Compared to the nonstate-owned PE, the state-owned PE (StatePE) can significantly increase their firms' approval probability (coefficient of 1.175 , at $5 \%$ levels of significance, in column 6 ). On the contrary, compared to non-foreign PE, foreign PEs (ForeignPE) cannot reduce or increase significantly the approved ratio of their holding enterprises (coefficient -0.248 , no significant, in column 7 ). Moreover, an enterprise with larger size, better profitability and reputable underwriter is more likely to be approved. These findings provide partly support for hypothesis H1b.

\subsection{IPO Underpricing}

In general, PE backed firms afford significantly higher financing costs in the IPO process. In table 6 the underpricing rate for PE-backed firms is no higher or lower than that of non PE-backed firms (column 8). While compared to other firms, the underpricing of reputable PE backed firms, State-owned PE backed firms, and foreign PE backed firms have no significant difference (column 9-11).

The results reject our Hypothesis 2a that underpricing for PE-backed enterprises is higher than for non PE-Backed firms and our Hypothesis $2 b$ that underpricing for enterprises backed by reputable PE firms is lower than for those backed by other PE firms.

\section{Table 7. The influence of PEs on IPO underpricing cost (OLS, H2a,H2b, Model 4.)}

Regressions for the influence of the PE background on the IPO underpricing rate. The sample is 254 IPO firms from 2009 to 2012 for column 15, and 104 PE-backed IPO firms from 2009 to 2012 for column 16, 17 and 18. The dependent variable is the IPO underpricing rate. Independent variables include the four kinds PE background dummy variables: PE equals to one if the firm is PE-backed, otherwise zero. ReputablePE equals to one if the PE is reputable, zero otherwise. StatePE equals to one if the PE is state 
PE, zero otherwise. ForeignPE equals to one if the PE is foreign PE, zero otherwise. The control variables include the logarithm of the firm's total assets one year before IPO (LogSize_1), the logarithm of the firm's age when IPO (LogAge), the dummy variable that equals to one if the underwriter is reputable, zero otherwise (Underwriter), the firm's offering $\mathrm{P} / \mathrm{E}$ ratio (OfferingP/E), the firm's return on assets one year before IPO (ROA_1), the firm's lottery rate for IPO (Lottery), the logarithm of the firm's trading volume on the first trading day (Logvolume), the firm's debt-to-asset ratio one year before IPO (Leverage_1), the firm's growth rate of the revenue one year before IPO (growth_1), the firm's logarithm of the issuing size one year before IPO (LogIssueSize), the industry dummy variables and the IPO year dummy variables. The brackets present $\mathrm{z}$ values, and $* * *, * *, *$ indicate $1 \%, 5 \%$, and $10 \%$ significance level respectively.

\begin{tabular}{|c|c|c|c|c|}
\hline \multirow[b]{2}{*}{ Independent variable } & \multicolumn{4}{|c|}{ Underpricing } \\
\hline & (8) & (9) & (10) & (11) \\
\hline \multirow[t]{2}{*}{$P E$} & 0.0442 & & & \\
\hline & $(1.24)$ & & & \\
\hline \multirow[t]{2}{*}{ ReputablePE } & & -0.0492 & & \\
\hline & & $(-0.87)$ & & \\
\hline \multirow[t]{2}{*}{ StatePE } & & & 0.0654 & \\
\hline & & & $(0.89)$ & \\
\hline ForeignPE & & & & 0.00174 \\
\hline & & & & $(0.02)$ \\
\hline \multicolumn{5}{|l|}{ Controls } \\
\hline \multirow[t]{2}{*}{ LogSize_1 } & 0.0701 & $0.309^{* *}$ & $0.278^{* *}$ & $0.307^{* *}$ \\
\hline & $(0.77)$ & $(2.31)$ & $(2.10)$ & $(2.34)$ \\
\hline \multirow[t]{2}{*}{ LogAge } & -0.0197 & -0.0376 & -0.0106 & -0.0168 \\
\hline & $(-0.41)$ & $(-0.67)$ & $(-0.17)$ & $(-0.27)$ \\
\hline \multirow[t]{2}{*}{ Underwriter } & -0.0305 & -0.0241 & -0.0498 & -0.0486 \\
\hline & $(-0.91)$ & $(-0.41)$ & $(-1.03)$ & $(-0.98)$ \\
\hline \multirow[t]{2}{*}{ OfferingP/E } & 0.000109 & $0.00552^{* * *}$ & $0.00476^{* *}$ & $0.00541^{* *}$ \\
\hline & $(0.07)$ & $(2.71)$ & $(2.14)$ & $(2.60)$ \\
\hline \multirow[t]{2}{*}{$R O A_{-} 1$} & 0.106 & $0.384^{* *}$ & $0.354^{* *}$ & $0.383^{* *}$ \\
\hline & $(0.96)$ & $(2.35)$ & $(2.24)$ & $(2.37)$ \\
\hline \multirow[t]{2}{*}{ Lottery } & -0.0152 & -0.0196 & -0.0253 & -0.0232 \\
\hline & $(-1.24)$ & $(-0.41)$ & $(-0.51)$ & $(-0.47)$ \\
\hline \multirow[t]{2}{*}{ LogVolume } & $0.194^{* * *}$ & $0.179^{* *}$ & $0.177^{* *}$ & $0.175^{* *}$ \\
\hline & $(3.80)$ & $(2.54)$ & $(2.52)$ & $(2.60)$ \\
\hline \multirow[t]{2}{*}{ Leverage_1 } & -0.00771 & 0.118 & 0.0731 & 0.103 \\
\hline & $(-0.04)$ & $(0.42)$ & $(0.26)$ & $(0.37)$ \\
\hline \multirow[t]{2}{*}{ Growth_1 } & $0.152^{* *}$ & $0.139^{* *}$ & $0.154^{* *}$ & $0.148^{* *}$ \\
\hline & $(2.57)$ & $(2.30)$ & $(2.54)$ & $(2.03)$ \\
\hline \multirow[t]{2}{*}{ LogIssueSize } & $-0.327^{* * *}$ & $-0.504^{* * *}$ & $-0.464^{* * *}$ & $-0.503^{* * *}$ \\
\hline & $(-3.38)$ & $(-2.96)$ & $(-2.77)$ & $(-2.99)$ \\
\hline \multirow[t]{2}{*}{ _cons } & 0.643 & -1.064 & -1.098 & -1.012 \\
\hline & $(0.85)$ & $(-1.01)$ & $(-1.07)$ & $(-0.96)$ \\
\hline & & $-21-$ & & \\
\hline
\end{tabular}




\begin{tabular}{|c|c|c|c|c|c|}
\hline & Industry & $\sqrt{ }$ & $\sqrt{ }$ & $\sqrt{ }$ & $\sqrt{ }$ \\
\hline & Year & $\sqrt{ }$ & $\sqrt{ }$ & $\sqrt{ }$ & $\sqrt{ }$ \\
\hline$r 2 \_a$ & & 0.47 & 0.56 & 0.56 & 0.56 \\
\hline$N$ & & 249 & 100 & 100 & 100 \\
\hline
\end{tabular}

In a robustness check, we apply the selection model (Heckman model) to deal with

possible self-selection bias. After we have controlled endogeneity problems, the PE can still

enhance the approval rate as shown in Table 8 and still have no significant effect on

underpricing rate as shown in Table 9.

\section{Table 8 Heckman model to control for self-selection bias about the effect of PE on}

\section{Approval}

Here are regressions of the control for self-selection bias about the effect of PE on approval. The sample is 357 firms apply for listing from 2009 to 2012. In the first stage, the dependent variable is the PE dummy (1 if the firms is PE-backed, otherwise 0). Control variables include the logarithm of the firm's total assets one year before approval (LogSize_1), the logarithm of the firm's age when approval for IPO (LogAge), the firm's return on assets one year beore approval (ROA_1), the industry dummy variables and the censor year dummy variables. In the second stage, the dependent variable is the approval dummy ( 1 if listing approval, otherwise 0). Independent variable is PE, equals to one if the firm is PE-backed, otherwise zero. The control variables include the Inverse Mills ratio from the first step regression, the logarithm of the firm's age when approval for IPO (LogAge), the logarithm of the firm's total assets one year before approval (LogSize_1), the firm's return on assets one year before approval (ROA_1), the firm's asset-liability ratio one year before approval (BS_1), the dummy variable that equals to one if the underwriter is reputable, zero otherwise (Underwriter), the logarithm of the firm's operational risk factors disclosed in the prospectus one year before approval (Logrisk), the logarithm of the number of the firm's patented copyright and non-patented technology (Logpatent), the sentiment of the secondary market to measure the metronome for IPO frequency (Logindex), the industry dummy variables and the censor year dummy variables. The brackets present $\mathrm{z}$ values, and $* * *, * *, *$ indicate $1 \%, 5 \%$, and $10 \%$ significance level respectively.

\begin{tabular}{lc|lc}
\hline \multicolumn{2}{c|}{ First Stage } & \multicolumn{2}{c}{ Second Stage } \\
\hline LogSize_1 & & \multicolumn{2}{c}{ Approval } \\
& $0.305^{* *}$ & PE & $0.471^{* *}$ \\
LogAge & $(2.11)$ & & $(2.03)$ \\
& -0.0831 & Lambda & -5.178 \\
ROA_1 & $(-0.41)$ & & $(-0.85)$ \\
& $0.402^{*}$ & LogAge & 0.168 \\
Cons & $(1.86)$ & & $(0.39)$ \\
& $-4.165^{* *}$ & LogSize_1 & -0.633 \\
Industry & $(-1.98)$ & & $(-0.47)$ \\
Year & $\sqrt{ }$ & ROA_l & -0.183 \\
& $\sqrt{ }$ & & $(-0.10)$ \\
\hline
\end{tabular}




\begin{tabular}{lc|lc}
\hline chi2 & 27.79 & BS_l & $2.110^{* *}$ \\
Log likelihood & -215.502 & & $(1.98)$ \\
Pseudo 2 & 0.07 & Underwriter & 0.282 \\
$N$ & 348 & & $(1.37)$ \\
& & LogRisk & 0.194 \\
& LogPatent & $(0.65)$ \\
& & -0.0362 \\
& LogIndex & $(-0.39)$ \\
& & 1.760 \\
& & $(1.47)$ \\
& & -3.446 \\
& & $(-0.14)$ \\
& Industry & $\sqrt{ }$ \\
& Year & $\sqrt{ }$ \\
& chi2 & 0.02 \\
& Log likelihood & -107.98 \\
& Pseudo R2 & 0.15 \\
& & 281 \\
\hline
\end{tabular}

\section{Table 9 Heckman model to control for self-selection bias about the effect of PE on}

\section{Underpricing}

Here are regressions of the control for self-selection bias about the effect of PE on IPO underpricing rate. The sample is 357 firms apply for listing from 2009 to 2012. In the first stage, the dependent variable is the PE dummy ( 1 if the firms is PE-backed, otherwise 0 ). Control variables include the logarithm of the firm's total assets one year before IPO (LogSize_1), the logarithm of the firm's age when IPO (LogAge), the firm's return on assets one year before IPO (ROA_1), the industry dummy variables and the year dummy variables. In the second stage, the dependent variable is the IPO underpricing rate. Independent variable is PE, equals to one if the firm is PE-backed, otherwise zero. The control variables include the Inverse Mills ratio from the first step regression, the logarithm of the firm's total assets one year before IPO (LogSize_1), the logarithm of the firm's age when IPO(LogAge), the dummy variable that equals to one if the underwriter is reputable, zero otherwise (Underwriter), the firm's offering $\mathrm{P} / \mathrm{E}$ ratio (Offering $\mathrm{P} / \mathrm{E}$ ), the firm's return on assets one year before IPO (ROA_1), the firm's lottery rate for IPO (Lottery), the logarithm of the firm's trading volume on the first trading day (Logvolume), the firm's debt-to-asset ratio one year before IPO (Leverage_1), the firm's growth rate of the revenue one year before IPO (growth_1), the firm's logarithm of the issuing size one year before IPO (LogIssueSize), the industry dummy variables and the IPO year dummy variables. The brackets present $\mathrm{z}$ values, and $* * *, * *, *$ indicate $1 \%, 5 \%$, and $10 \%$ significance level respectively.

\begin{tabular}{cc|cc}
\hline \multicolumn{2}{c|}{ First stage } & \multicolumn{2}{c}{ Second stage } \\
\hline \multicolumn{2}{c|}{$P E$} & & Underpricing \\
\hline \multirow{2}{*}{ LogSize_1 } & $0.388^{* *}$ & $\boldsymbol{P E}$ & 0.0467 \\
& $(2.06)$ & & $(1.32)$ \\
\hline \hline
\end{tabular}

$-23-$ 


\begin{tabular}{|c|c|c|c|}
\hline LogAge & $\begin{array}{c}0.0919 \\
(0.37)\end{array}$ & Lambda & $\begin{array}{c}0.347^{* *} \\
(2.59)\end{array}$ \\
\hline$R O A \_l$ & $\begin{array}{l}0.443^{*} \\
(1.64)\end{array}$ & LogSize_1 & $\begin{array}{l}0.176^{*} \\
(1.77)\end{array}$ \\
\hline _Cons & $\begin{array}{l}-5.223^{* *} \\
(-1.99)\end{array}$ & LogAge & $\begin{array}{l}0.0101 \\
(0.21)\end{array}$ \\
\hline $\begin{array}{l}\text { Industry } \\
\text { Year }\end{array}$ & $\begin{array}{l}\sqrt{ } \\
\sqrt{ }\end{array}$ & Underwriter & $\begin{array}{c}-0.0267 \\
(-0.80)\end{array}$ \\
\hline chi2 & 29.01 & OfferingP/E & 0.000334 \\
\hline Log likelihood & -150.34 & & $(0.22)$ \\
\hline Pseudo R2 & 0.10 & $R O A \_1$ & $0.222^{*}$ \\
\hline \multirow[t]{11}{*}{$N$} & 249 & & $(1.89)$ \\
\hline & & Lottery & $\begin{array}{c}-0.0133 \\
(-1.11)\end{array}$ \\
\hline & & LogVolume & $\begin{array}{c}0.181^{* * *} \\
(3.57)\end{array}$ \\
\hline & & Leverage_1 & $\begin{array}{c}-0.0313 \\
(-0.18)\end{array}$ \\
\hline & & Growth_1 & $\begin{array}{c}0.169^{* * *} \\
(2.88)\end{array}$ \\
\hline & & LogIssueSize & $\begin{array}{c}-0.354^{* * *} \\
(-3.69)\end{array}$ \\
\hline & & _cons & $\begin{array}{l}-0.567 \\
(-0.53)\end{array}$ \\
\hline & & Industry & $\sqrt{ }$ \\
\hline & & Year & $\sqrt{ }$ \\
\hline & & $r^{2} \_a$ & 0.49 \\
\hline & & $N$ & 249 \\
\hline
\end{tabular}

\section{Conclusion}

We use a novel hand-collected dataset of ChiNext listed enterprises backed by PE (also called Pre-IPO PE, or quick flippers) to answer the research question of why enterprises accept PE capital shortly before IPO under China's institutions.

Using information obtained from listing prospectuses, we shed light on the applicability of the explanations in a Chinese context. Firstly, we find that PE firms significantly increase the enterprises' probability of approval when they apply to the CSRC for IPO. Secondly, the acceptance rate for enterprises backed by reputable PE firms is significantly higher than that 
for non-reputable PE firms. Thirdly, we find that introduction of PE does not certify the quality of the enterprise as it leads to underpricing that is not significantly higher or lower compared with non-PE-backed firms. The main results are summarized in Table 10.

Table10. The main hypothesis, methods and findings.

\begin{tabular}{lll}
\hline \hline \multicolumn{1}{c}{ Hypothesis } & \multicolumn{1}{c}{ Methods and results } & \multicolumn{1}{c}{ Findings/Outcome } \\
\hline $\begin{array}{l}\text { H1a: PE improves the } \\
\text { approval probability at } \\
\text { CSRC }\end{array}$ & $\begin{array}{l}\text { The probit model shows that PE backed } \\
\text { firms have a significantly higher } \\
\text { approval probability. }\end{array}$ & $\begin{array}{l}\text { Yes. Significant } \\
\text { increase }\end{array}$ \\
\hline $\begin{array}{l}\text { H1b: PE reputation } \\
\text { improves the approval } \\
\text { probability at CSRC }\end{array}$ & $\begin{array}{l}\text { The probit model shows that enterprises } \\
\text { that accept reputable PE, state-owned PE } \\
\text { have a better chance of listing approval. }\end{array}$ & $\begin{array}{l}\text { Yes. Significant } \\
\text { increase. }\end{array}$ \\
\hline $\begin{array}{l}\text { H2a: PE increases the } \\
\text { cost of IPO } \\
\text { (underpricing) }\end{array}$ & $\begin{array}{l}\text { The OLS regression model shows that } \\
\text { PE-backed firms have no different }\end{array}$ & No. \\
& $\begin{array}{l}\text { underpricing compared with non } \\
\text { PE-backed firms. }\end{array}$ & \\
H2b: Reputable PE & The OLS regression model shows that & No \\
decreases the cost of & $\begin{array}{l}\text { reputable PE-backed firms have no } \\
\text { different underpricing compared with non }\end{array}$ & \\
& reputable PE-backed firms. & \\
& & \\
\end{tabular}

In answer to the research questions, on the positive side, ChiNext enterprises appear to accept PE since PE it improves the enterprise's chance of being approved for listing by CSRC. On the negative side, PE investment leads to no lower underpricing compared to those firms without PE.

Our findings add to the certification literature that has looked at certification to the market by looking at the importance of certification to stock market regulators in an environment of limited development of markets. We also add to recent work that has shown differences in the impact on underpricing of the presence of a PE. Studies in developed markets have variously shown higher or lower underpricing but we show that there is no significant effect for the early stage market in China. This is consistent with the total first day return finding of Jiang et al (2014) who studied all VC backed IPOs on both the main(small and medium enterprises board, SME) and ChiNext markets. Also consistent with Jiang et al 
(2014) our findings relating to those PE firms who invested for only two years prior IPO do not support a grandstanding hypothesis that PE firms are taking firms to IPO prematurely. This may suggest that PE firms are investing in these firms at the point where the focus needs to be on preparing them for IPO. It is interesting that our findings of no significant effect in reducing underpricing are consistent with those relating to China's main market which show that the presence of a $\mathrm{VC} / \mathrm{PE}$ investor does not reduce underpricing.

The lack of a significant finding regarding underpricing even in respect of reputable PE firms but a significant finding regarding approval may indicate that regulatory decisions are influenced by their connections with PE firms rather than the quality of the IPO firm. The special approval system of the CSRC increases the financing costs of enterprises, but may also encourage PE institutions to engage in lobbying activities which represents a deviation from the original intention of the Chinese government, who want to promote industrial upgrading and improve the financing environment of small-medium sized enterprises aided through the birth of the ChiNext board. Alternatively, our findings may indicate a difference in expertise between regulators and investors. Due to lack of data transparency, we are unable to tease out in a quantitative analysis which explanation is the stronger. Anecdotally, there are indications of inappropriate collusion between some PE firms and the regulators, for example in the case of the LETV IPO and with respect to allegations of bribery involving former senior officials of the CSRC.

Our findings have implications for policy. To the extent that they reflect shortcomings in the IPO approval system, we suggest improvements are needed to the current approval offering system in ChiNext. The reforms to the SIEVC noted earlier regarding the setting up of a selection committee, making the process more open and transparent, and the strengthening of the supervision and management of the SIEVC operation are aimed at making the approval system more robust. Further, regulators could reduce the offering threshold and provide fair financing opportunities for all enterprises. We also suggest that potential candidates for listing that have a PE backer should be assessed in terms of including whether and how the PE firm has actually added value over its holding period. In order to reduce favoritism, industry specialists on the SIEVC as well as individuals who are not directly connected to the PE industry should be included on the SIEVC panel and decisions 
about listings should be more transparent.

The limitations of the paper which open up opportunities for further research are as follows. Firstly, as noted, we cannot provide direct evidence on the lobbying actions used by the $\mathrm{PE}$ in relation to obtaining approval by the CSRC. More research is needed with the PE firms and ChiNext listed firms to examine this issue. However, obtaining in-depth understanding of PE institutions' lobbying behaviors is notoriously difficult due to its non-transparent nature. (In the case of LETV, the relationship between the listed company, the PE Huijin Cube, the SIEVC members, and CSRC senior officials Li Liang and Yao Gang has been made public). We have only discussed the PEs' role through a public offering process. But market power and other factors are also considered by enterprises when they decide to obtain finance from PEs (Chemmanur and Loutkina, 2006). A further study should consider these factors. Finally, the ChiNext market is quite new with a very short history and data limitations regarding the immaturity of the market may be influencing the results.

\author{
Acknowledgements \\ We appreciate helpful comments from Jun Qian (Boston College), Zhishu Yang (Tinghua university), \\ and Wei Li (East China Normal University), and conference participants at the 2011 China International \\ Conference in Finance (CICF ,Wuhan,China), 2013China Conference of Finance at Peking \\ University(Beijing, China), the Capital Market and Financial Innovation International Convention at SUFE \\ 2013, and 5th Chinese Capital Markets Conference (2015,in Manitoba, Canada).
}

\title{
Funding
}

Yao Li acknowledges the financial support of National Social Science Fund of China (13BJL038). 
Notes:

(1) In 2013, China's IPO was suspended. In the period 2014-2017, the number of IPO per year in ChiNext was between 50-150 enterprises, accounting for 1/3-1/2 of the total number of IPO enterprises in China. And in 2017 ChiNext IPO numbers were 141 enterprises.

${ }^{2}$ Usually investments held for less than 2 years are referred as quick flips in the private equity industry See Blenman and Reddy (2014).

(3) In June 1993, the CSRC decided to establish SIEVC as one of the most core and essence system designs of Chinese securities market. Since then the SIEVC has lasted for 24 years until 2017.During the period ChiNext was set up in 2009. So the SIEVC has two affiliates, one is for main board (including 25 committee members, for 16 sessions), the other is for ChiNext (including 35 committee members, for 6 sessions). In July 2017 CSRC announced the revised SIEVC policy: 1. To combine the two affiliates into one. The total committed members are increased from 60 to 66 . A committee member's continual tenure should not surpass two sessions instead of three sessions, and the committee should at least replace one half members every year. 2. To establish two new sub-committees, the selection committee and the supervision committee, in SIEVC. In this way, the principle of the separation of selection, operation, and supervision by committee members can be achieved. The SIEVC reform is necessary. Some scandals about SIEVC emerged recently. For example, one former committee member of SIEVC, Feng Xiao Shu, made a stir in the market in 2017. When Mr.Feng was an officer of the Shenzhen Stock Exchange and a part-time member of SIEVC, he illegally earned 248 million Yuan from only 3 million Yuan investment by inside trading in just three years service in SIEVC. The CSRC confiscated the illegal income and imposed a fine of 251 million Yuan along with a lifetime ban on his involvement in the securities market.

(4) Fan, Wong, and Zhang (2007) define a firm as politically connected if either the Chairman or CEO currently serves or formerly served in the government or military. Liu, Tang and Tian (2014)use a definition that includes firms whose chairman or CEO serves/served as a deputy of National People's Congress(NPC) or the Chinese People's Political Consultative Conference(CPPCC) because both of them are important authorities in the Chinese central and local governments. Bao et al. (2016) also use the CEO and other board directors' political connections as: (1) a current or former member of the National People's Congress (NPC); (2) a current or former member of the Local People's Congress (LPC); and (3) a current or former member of the Chinese People's Political Consultative Conference (CPPCC).

(5) We tried to collect the PE partner's information from the public disclosure of their personal profiles. Most of them are not NPC or CPPCC member (see Fan et al., 2007; Liu et al., 2014; Bao et al., 2016). Many of the profiles of PE general partners are undisclosed, and you can't read between the lines from those disclosed personal profiles. But the surface doesn't reveal the essence. Here are three famous anecdotes in China PE industry. 1.One of the former general partners of New Horizon Capital, a famous Chinese PE firm, is the son of Mr. Wen Jiabao, the former Premier of China. 2.The incumbent CEO of CITIC industry investment fund(called CITICPE, listed as No. 78 in World PE 300 by PEI in 2017), Liu Lefei, is the son of Liu Yunshan, current member of Politburo Standing Committee of Communist Party of China. These PE partners very likely have powerful networks. 3. Huijin Cube, a secretive PE firm, specializes in investment of Pre-IPO projects and then getting them listed on the ChiNext. Its chairman, Wang Cheng, is a pseudonym. His real background is that he is Ling Jihua's younger brother. Ling Jihua is the former vice chairman of the CPPCC National Committee, former director of General Office of the CPC Central Committee, found guilty of accepting bribes, illegally obtaining state secrets, breach of privilege crimes, who was sentenced to life imprisonment in 2016.

${ }^{\circ}$ In this paper's research period, the majority of PE in the Chinese market is engaged in what is called the pre-IPO PE investment (defined as less than two years before IPO , that is ,quick flipper.), in order to obtain the return, also to establish the prestige as soon as possible. The paper omits the PE whose investment holding period surpasses 2 years before IPO.

(7) According to the 2007 China's Ministry of Finance and the State Administration of Taxation " 
Notice on tax policy on promoting the development of venture capital investment enterprises", if the equity investment of venture capital in China has been invested in unlisted small and medium-sized high-tech enterprises for more than two years (including two years), the taxable income of the venture capital can be deducted by $70 \%$ of the investment.

${ }^{8}$ ChiNext started on September 17, 2009. The IPOs of Chinese stock exchanges (including ChiNext and the main boards of Shanghai and Shenzhen) were all suspended by CSRC from November 3, 2012 until January 17, 2014. That means CSRC ceased new stock release examination and approval during the period. The main reason is the reform of the IPO system by CSRC.

${ }^{9}$ The CSMAR (China Stock Market Accounting Research) database was developed by GTA IT Co. in 1999 in order to meet the demands of the Chinese financial market information from financial institutions, researchers, and academic scholars.

(1) WIND is the first China financial electronic database which was established in 1994, and now a leading financial information provider aimed at being a Chinese Bloomberg.

11 The reasons are as: (1)Our hand-collected data includes 494 sample companies, among whose shareholders there are 975 PE institutions. From the prospectus we know all shareholders of the firms before IPO. Many of these PE institutions' shareholding ratio is not high enough to be in the list of the "top ten shareholders". (2) We find there are at least 196 shareholders' names containing key words such as "investment", "venture capital ", "private equity", "venture", etc. But by checking the biography of the shareholders we find these institutions should not be classified as PE investors as they have close relationship with the de facto controlling holders or the founders, managers of the enterprises, and many of the institutions are established with the aim to execute manager/employee stock incentive schemes. These institutions should be excluded from the PE investors. (3) Additionally, we find that some shareholders should be counted as PE investors although their names do not contain words of PE or VC. This can be verified by checking the main business of these institutions in the shareholder profiles.

12 China Venture Capital Annual Ranking was initiated by Zero2IPO Group in 2001 based on overall surveys on aspects as investment, management, fundraising, exit, and so on. Ranking indicators are modified on a yearly basis according to the actual development. Since 2006, Zero2IPO has also introduced the ranking list of private equity investment institutions in the annual ranking. China Venture Capital \& Private Equity Annual Ranking by Zero2IPO Group has won high recognition by domestic and overseas venture capital and private equity institutions, and it has been widely cited by well-known financial media at home and abroad. In 2007-2010, the ranking annually gives Top 10 private equity firms and Top 20 venture capital firms in China.

13 The CSRC requests the application materials for IPO /and also the later prospectus should include such a part of 'risk disclosure'. The applicant firm and underwriter should disclose the risk factors as price fluctuation, financial risk, management risks and so on in red-herring materails/prospectus, so that CSRC will understand the impact of the risk factors may affect the company's profits. If there are more factors, the company may be believed with more risks. So it may influence the CSRC judgment of approval. So we include the 'risk factors'in Approval regression.

14 In China's new stock offering, the lead underwriter and the issuing firm determine the primary offering price through book building process. The IPO market is divided into the online and offline markets, in which individual and institutional investors subscribe the new shares online and offline separately. When investors 'effective subscription is bigger than the new shares quantity, the stock exchange will allocate sequent numbers automatically by system computer according to every 1000 shares subscription. Then the exchange computer will determine the lucky numbers by lottery. Each luck number will be entitled to buy 1000 shares. The lottery rate is: Lottery rate $=$ new offering shares/all effective subscription shares $* 100 \%$. And that forms the online and offline lottery rates. The online lottery rate is usually an indicator to represent investors' emotions.

15 The ChiNext listing requirements issued by CSRC are mainly on profitability. The applicant 
should have continuous profits and accumulated net profits no less than 10 million Yuan in the last two years before application. Or the applicant has profit and the most recent annual revenue of no less than 50 million Yuan in the last year.

\section{References}

Baker M and Gompers PA (2003). The determinants of board structure at the initial public offering. Journal of Law and Economics 46(3): 569-598.

Bao X., Johan, S and Kutsuna K. (2016) Do political connections matter in accessing capital markets? Evidence from China . Emerging Markets Review 29: 24-41

Beatty RP and Ritter JR (1986) Investment banking, reputation, and the underpricing of initial public offerings. Journal of Financial Economics 15(1-2): 213-232.

Berkman, H., Cole RA and Fu LJ (2014). Improving corporate governance where the State is the controlling block holder: evidence from China. European Journal of Finance, 20, 7-9, $752-777$.

Brav A and Gompers PA (1997) Myth or reality? The long-run performance of initial public offerings: evidence from venture and non-venture capital-backed companies. Journal of Finance 52(5): 1791-1821.

Bruton, G. D. and Ahlstrom, D. (2003) An institutional view of China's venture capital industry explaining the differences between China and the West, Journal of Business Venturing 18 (2): 233-259.

Campbell II TL and Frye MB (2009) Venture capitalist monitoring: Evidence from governance structures. Quarterly Review of Economics and Finance, 49(2): 265-282.

Chemmanur TJ and Loutskina E (2006) The role of venture capital backing in initial public offerings: certification, screening, or market power? SSRN working paper.

Chen GM, Yu X., and Kou XH (2011) The underpricing of venture capital backed IPOs: evidence from Chinese firms listed on different stock markets. Economic Research Journal 46(5): 74-85. (In Chinese).

Cressy R, Munari F and Malipiero A (2007) Playing to their strengths? Evidence that specialization in the private equity industry confers competitive advantage. Journal of Corporate Finance 13(4): 647-669.

Cumming D., Guarigliab A., Hou W. and Lee E. (2014). The experiences and challenges in the development of the Chinese capital market. European Journal of Finance, 20, 7-9, 595-598. 
Gompers PA (1996) Grandstanding in the venture capital industry. Journal of Financial Economics 42(1): 133-156.

Deng, Q. and Zhou, Z. (2016a) Overreaction in Chinext IPOs' initial returns: how much and what caused It? Emerging Markets Review 29: 82-103.

Deng, Q. and Zhou, Z. (2016b) The pricing of first day opening price returns for Chinext IPOs. Review of Quantitative Finance and Accounting 47: 249-271.

Di Guo, K.J. (2013) Venture capital investment and the performance of entrepreneurial firms: Evidence from China. Journal of Corporate Finance, (22): 375-395.

Heckman JJ and Todd PE (2009) A note on adapting propensity score matching and selection models to choice based samples. NBER Working Papers 15179.

Heckman JJ and Honore BE (1990) The empirical content of the Roy model.Econometrica 58(5): 1121-1149.

Jiang P., Cai C. X., Keasey K., Wright, M., and Zhang Qi. The role of venture capitalists in small and medium-sized enterprise initial public offerings: Evidence from China. International Small Business Journal September 2014 (32): 619-643.

Johnson WC and Sohl JE (2008) IPOs and pre-IPO shareholders: angels versus venture capitalists. SSRN Working paper.

Kaplan SN and Stromberg P (2001) Venture capitalists as principals: contracting, screening, and monitoring. American Economic Review 91(2): 426-430.

Kaplan SN and Stromberg P. (2009) Leveraged buyouts and private equity.Journal of Economic Perspectives 23(1): 121-146.

Kou X, Pan L. and Ding C. (2009) The role of venture capital for small and medium-sized enterprises IPO firms' performance. Securities market herald 202: 10-25. (In Chinese).

Landström H (ed) (2007) Handbook of Research in Venture Capital. Cheltenham: Edward Elgar.

Lee PM, and Wahal S (2004) Grandstanding, certification, and the underpricing of venture capital backed IPOs. Journal of Financial Economics 73(2): 375-407.

Lerner J, Hardymon F and Leamon A (2004) Venture capital and private equity: A casebook. $3^{\text {rd }}$ edition. New York: John Wiley \& Sons. 
Lerner J (2010) Innovation, entrepreneurship and financial market cycles.OECD Science, Technology and Industry Working Papers 2010/3: OECD Publishing.

Liu Y and Xiong P (2005) Equity separation, government regulations, and Chinese IPO underpricing puzzle. Economic research Journal 40(5): 85-95. (In Chinese).

Ljungqvist A (2007) IPO underpricing. In EspenEckbo B (ed) Handbook of Corporate Finance: Empirical Corporate Finance, Volume 1. Amsterdam: Elsevier/North-Holland, pp. $375-422$.

Ljungqvist A, Nanda V and Singh R (2006) Hot markets, investor sentiment, and IPO pricing.Journal of Business 79(4): 1667-1702.

Loughran T and Ritter JR (2002) Why don't issuers get upset about leaving money on the table in IPOs?Review of Financial Studies 15(2): 413-444.

Luo Y, (2000). Guanxi and Business. World Scientific Press, Singapore.

McChesney FS (1987) Rent extraction and rent creation in the economic theory of regulation. Journal of Legal Studies 16(1): 101-118.

Megginson WL and Weiss KA (1991) Venture capitalist certification in initial public offerings. Journal of Finance 46(3): 879-904.

Nahata R (2008) Venture capital reputation and investment performance. Journal of Financial Economics90(2): 127-151.

Neus W and Walz U (2005) Exit timing of venture capitalists in the course of an initial public offering. Journal of Financial Intermediation 14(2): 253-77.

Otchere I and Vong, A (2016)Venture capitalist participation and the performance of Chinese IPOs. Emerging Markets Review 29: 226-245

Ritter JR and Welch I (2002) A review of IPO activity, pricing, and allocations. Journal of Finance 57(4): 1795-1828.

Ritter JR (2003) Behavioral finance. Pacific-Basin Finance Journal 11(4): 429-437.

Sahlman WA (1990) The structure and governance of venture capital organizations. Journal of Financial Economics 27(2): 473-521.

Stigler GJ (1971) The theory of economic regulation. Bell Journal of Economics and Management Science 2(1): 3-21. 
Suchard JA (2009) The impact of venture capital backing on the corporate governance of Australian initial public offering. Journal of Banking and Finance 33(4): 765-774.

Wang KC, Wang K and Lu Q (2003) Effects of venture capitalist's participation in listed companies. Journal of Banking and Finance 27(10): 2015-2034.

Wright M (2007) Venture capital in China: A view from Europe. Asia Pacific Journal of Management 24(3): 269-281.

$\mathrm{Xu} \mathrm{H}$ and Luo W (2007) Investment bank reputation mechanism, service quality and effective market share double perspective research. Economy Research Journal 42(2): 124-136. (In Chinese).

Yeung I Y M, Tung R L.(1996) Achieving business success in Confucian societies: The importance of guanxi (connections). Organizational Dynamics, 25(2):54-65.

Zhang X and Liao (2011) Venture capital funds' backgrounds, IPO underpricing and post-IPO performance. Economy Research Journal. 46(6): 118-132. (In Chinese).

Zhao Y and Lu Y (2009) The relationship between venture capital and listed firms' performance: evidence from small and medium-sized enterprises in China. Science and technology development and strategy 23: 24-30. (In Chinese).

Zhu G and Qian Y (2010) Chinese IPO underpricing puzzle: pricing efficiency or rent allocation? Management World 203: 28-40 (In Chinese) 